\title{
From Research to Practice and Back Again: TIMSS as a Tool for Educational Improvement
}

Marlies Dunson

Follow this and additional works at: https://repository.upenn.edu/cpre_policybriefs

Part of the Educational Assessment, Evaluation, and Research Commons, Educational Methods Commons, Education Policy Commons, and the Science and Mathematics Education Commons

\section{Recommended Citation}

Dunson, Marlies. (2000). From Research to Practice and Back Again: TIMSS as a Tool for Educational Improvement. CPRE Policy Briefs.

Retrieved from https://repository.upenn.edu/cpre_policybriefs/18

View on the CPRE website.

This paper is posted at ScholarlyCommons. https://repository.upenn.edu/cpre_policybriefs/18

For more information, please contact repository@pobox.upenn.edu. 


\title{
From Research to Practice and Back Again: TIMSS as a Tool for Educational Improvement
}

\author{
Abstract \\ The U.S. Department of Education released data from the Third International Mathematics and Science \\ Study (TIMSS) to serve as a "starting point to examine U.S. education, student achievement, teaching and \\ curricula." The researchers and administrators of TIMSS hoped that these findings would provoke \\ reflective discussions by providing a different lens through which schools could reevaluate their current \\ practices and education policymakers could benefit from new insights. In the three years following the \\ release of the first set of data, a number of states, districts, and schools have delved deeply into TIMSS \\ for policy development and school improvement, receiving assistance through meaningful collaborations. \\ U.S. researchers, practitioners, and policymakers have been working together with data from TIMSS and \\ other research studies to generate viable solutions for improving student achievement in mathematics \\ and science. \\ This Policy Brief stems from one such effort-a TIMSS Policy Forum that was held in Washington, D.C. in \\ 1999. At the Forum, researchers described the questions they were seeking to answer using TIMSS data, \\ and practitioners and state and local policymakers described the tactics they were taking to support \\ school improvement using those research findings. The interdependence among research, policy, and \\ practice demonstrated at the Forum and reported in this Brief serves as a model for a national \\ conversation on education that is grounded in both information and its practical application. \\ The initiatives, outlined below, undertaken in the three districts, one school, and one state illustrate the \\ impact that meaningful data and useful interpretations of those data can have on education policy and \\ practice. By closely comparing and contrasting the curricula, teaching practices, professional \\ development, and administration policies of many countries, researchers, policymakers, and practitioners \\ can jointly assess what might work best for students in the United States.

\section{Disciplines} \\ Educational Assessment, Evaluation, and Research | Educational Methods | Education Policy | Science \\ and Mathematics Education

\section{Comments} \\ View on the CPRE website.
}




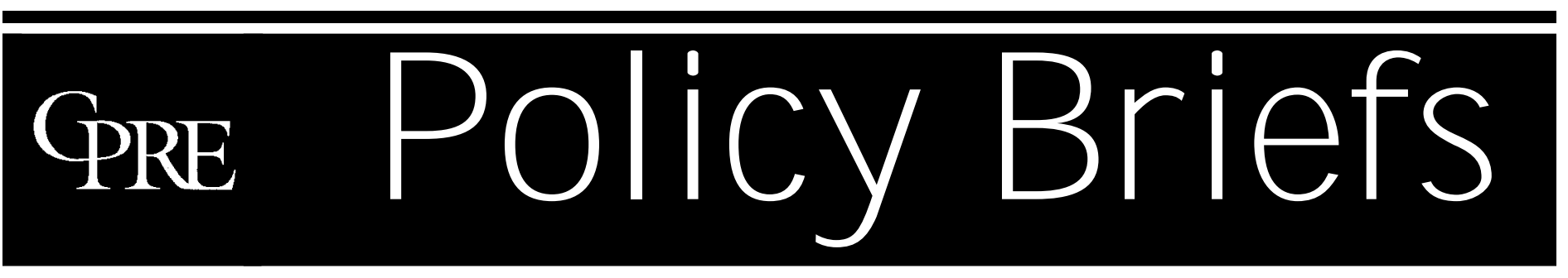

Reporting on issues in education reform

Graduate School of Education - $\quad$ University of Pennsylvania - RB-30-April 2000

\title{
From Research to Practice and Back Again: TIMSS as a Tool for Educational Improvement
}

\author{
by Marlies A. Dunson
}

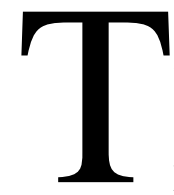

he U.S. Department of Education released data from the Third International Mathematics and Science Study (TIMSS) to serve as a "starting point to examine U.S. education, student achievement, teaching and curricula." 1 The researchers and administrators of TIMSS hoped that these findings would provoke reflective discussions by providing a different lens through which schools could reevaluate their current practices and education policymakers could benefit from new insights. In the three years following the release of the first set of data, a number of states, districts, and schools have delved deeply into TIMSS for policy development and school improvement, receiving assistance through meaningful collaborations. U.S. researchers, practitioners, and policymakers have been working together with data from TIMSS and other research studies to generate viable solutions for improving student achievement in mathematics and science.

This Policy Brief stems from one such effort—a TIMSS Policy Forum that was held in Washington, D.C. in 1999. At the Forum, researchers described the questions they were seeking to answer using TIMSS data, and practitioners and state and local policymakers described the tactics they were taking to support school improvement using those research findings. The interdependence among research, policy, and practice demonstrated at the Forum and reported in this Brief serves as a model for a national conversation on education that is grounded in both information and its practical application.

The initiatives, outlined below, undertaken in the three districts, one school, and one state illustrate the impact that meaningful data and useful interpretations of those data can have on education policy and practice. By closely comparing and contrasting the curricula, teaching practices, professional development, and administration policies of many countries, researchers, policymakers, and practitioners can jointly assess what might work best for students in the United States.

\footnotetext{
The Consortium for Policy Research in Education (CPRE) studies alternative approaches to education reform in order to determine how state and local policies can promote student learning. Currently, CPRE's work is focusing on accountability policies, efforts to build capacity at various levels within the education system, methods of allocating resources and compensating teachers, and governance changes like charters and mayoral takeover. The results of this research are shared with policymakers, educators, and other interested individuals and organizations in order to promote improvements in policy design and implementation. CPRE is supported by the National Institute on Educational Governance, Finance, Policymaking and Management, Office of Educational Research and Improvement, U.S. Department of Education.
} 


\section{Practitioners' Efforts to Use TIMSS}

\section{First in the World Consortium}

The First in the World Consortium grew out of the conversations of a study group of superintendents who initially met to fulfill a requirement for recertification. After meeting several more times, they decided to form a consortium that focused on Goal 5 of the National Education Goals: To be the first in the world in math and science by the year 2000. In this effort, First in the World-which unites 18 school districts in the suburbs surrounding Chicago, Illinois-received permission to participate in the TIMSS as a self-contained unit in order to benchmark the performance of its schools against international measures of student performance.

Leaders of First in the World obtained technical, administrative, and research support from partnerships established with the business community and with key education organizations, such as the U.S. Department of Education and the North Central Regional Educational Laboratory. With that support, First in the World created "learner networks" so teachers, principals, and superintendents could study and discuss important issues like performance expectations, instructional practices, teacher characteristics, technology, assessment, and the structure and content of curricula. The discussions stemmed from 13 research questions, four of which follow:

- Do school programs in the Consortium reflect a "worldclass" curriculum?

- What instructional practices in the Consortium make a difference in student achievement?

- Does curriculum in Consortium schools "fit" with international standards?
- How do the social and cultural contexts differ between Consortium schools and countries around the world?

To answer these and other research questions, First in the World began the following initiatives: 1) producing a curriculum analysis for each district, which compares the district to the highest achieving countries in the world and which provides guidelines for four areas of local analysis leading to improvements; 2) developing a comprehensive mathematics and science curriculum framework for K-8 that supplies a sequence of mathematics and science content standards and performance expectations; ${ }^{3} 3$ ) reporting on the research questions, including the data sources, methodology, findings/results, and implications for school districts; 4) participating in the TIMSS-R videotape study in both mathematics and science instruction at the eighth grade level; and 5) developing "Lesson Study Groups" at the Consortium level as well as the local district level.

The Consortium leadership recognized early on the unique nature of the 18 school districts. It also accepted the fact that each district individually would be addressing priorities and devoting resources and energy to accomplish those distinctive priorities. Therefore, it was determined from the start that all of the Consortium findings would be processed and implemented by each district within its own culture and in its own timing.

With that consideration, each of the five initiatives has raised the overall discussion about curriculum and instruction to a new level. "Comparisons at the international level and deep discussion about the focus, rigor, and flow of what we teach in addition to how we must raise the level of teaching has radically improved over the past three years," explained David Kroeze, Superintendent of Schools for the Northbrook School District \#27 (Illinois). He continued, "The Consortium has successfully institutionalized the need to look outside our environment for ways to challenge our assumptions of 'effective practice.",

\section{About CPRE Policy Briefs}

CPRE Policy Briefs are published by the Consortium for Policy Research in Education (CPRE). The research reported in this issue was supported by a grant (No. R215U980021) from the Fund for Improvement of Education, Office of Reform Assistance and Dissemination, Office of Educational Research and Improvement, U.S. Department of Education. The views expressed in this publication are those of its author and are not necessarily shared by the U.S. Department of Education, the Office of Educational Research and Improvement, CPRE, or its institutional members. 
The results of the TIMSS curriculum analysis reinforced prior research findings and strengthened First in the World's commitment to aligning curricula. The TIMSS results showed that, in spite of variable achievement scores, the U.S. curricula contain the largest variety of topics, and those topics tend to be repeated in more grades than in any other country. For example, researchers found that in the eighth grade, 38 topics were covered in U.S. mathematics textbooks, while an average of 23 topics were taught eighth grade textbooks in other countries. Yet, U.S. students had not received in-depth instruction in many concepts that TIMSS tested. According to TIMSS findings, the "basics" in the U.S. eighth grade math curriculum was quite different from the basics in other countries' programs. ${ }^{5}$

But it is not just the TIMSS findings on curricula that continue to influence the efforts of First in the World. Paul Kimmelman, Superintendent of Schools for the West Northfield School District \#31 (Illinois), wrote, “...TIMSS enables us to analyze each district's mathematics and science curriculum, compare instructional strategies of teachers in the United States, Germany, and Japan and learn what our students actually think about their behaviors in our schools." 6

\section{The SMART Consortium}

As public awareness and political pressure grew in Ohio over the results of TIMSS and other achievement measures, the Ohio legislature passed a school accountability law, which set minimum standards for school district performance and increased the rigor of Ohio's high school exit exams and graduation requirements. As part of its statewide strategies to improve mathematics and science, in March 1998 the staff at the Ohio Department of Education assembled a group of superintendents in the Cleveland area whose districts would comprise the Science and Mathematics Achievement Required for Tomorrow (SMART) Consortium. This Consortium, supported by the Ohio Department of Education and the Martha Holden Jennings Foundation, unites 19 school districts in northeast Ohio through the efforts of 19 superintendents. Combined, the districts serve more than 200,000 students from large urban areas such as Cleveland Municipal, affluent suburbs like Beachwood, and small rural towns like Kirtland Local.

The members of the SMART Consortium have committed to long-term systemic change and continuous improvement in mathematics and science by employing five big-picture strategies based on recommendations from action teams that studied the issues:
- Providing alignment in curriculum, instruction, assessment, and professional development using world class standards as a guide;

- Affecting the willingness of teachers and administrators to bring about change;

- Changing people's beliefs about the nature of learning;

- Developing and maintaining buy-in and support from the public, parents, students, school boards, business, industry, and the community; and

- Improving teaching and learning district by district using research-based education techniques.

SMART hopes to reach two "stretch goals," which were set forth by its member districts after several months of debate. The first goal is for districts to cut their student failure rate on state proficiency tests in half over the next five years. While the heterogeneity of the districts leads to the conclusion that they have different needs with respect to the achievement goal, the collaborative nature of the Consortium is resulting in joint efforts among districts, such as the development of a common course of study that will be implemented across the Consortium. Districts have realized that the improvement of public education is something that will not happen if districts, schools, and teachers continue to work in isolation. By working together, the expertise provided by each district can be used to the fullest.

The second stretch goal deals with the districts' capacity to provide for increased student achievement through its resources. This goal has several sub-goals that lay out program requirements for mathematics and science in elementary, middle, and high school:

- All school districts will require completion of elementary mathematics by the end of grade five;

- All school districts will require completion of an algebra I core by the end of eighth grade;

- All school districts will require completion of algebra II and geometry for graduation;

- All school districts will require completion of elementary science by the end of grade four; 
- All school districts will require completion of an integrated core of life, earth/space, and physical science by the end of eighth grade; and

- All school districts will require completion of physics, chemistry, earth/space, and biological sciences for graduation.

Each district will create an action plan that lays out the steps needed in that district to reach the stretch goals. These individual action plans will be used to determine how the collective resources of SMART can be used best.

Meanwhile, many efforts are currently underway to help teachers achieve the stretch goals. These include pilot implementation projects of new science instructional materials in the upper elementary grades, a pilot of a content-based professional development series for mathematics teachers in grades five through eight, the development of teacher learning networks, and the implementation of a principals' academy to provide better expertise in instructional leadership at the building level. As the districts formulate more detailed plans that will facilitate the achievement of the stretch goals, Consortium-level activities may shift in focus.

While the TIMSS provided the impetus for the formation of the SMART Consortium, the group continues to learn from the TIMSS findings as they conduct their activities. This is especially evident in the deliberations of the course of study committees, which are attempting to provide a focused curriculum to combat the "mile wide, inch deep" characteristic that permeates American curricula. Eighth graders took the TIMSS-R in spring 1999, and the Consortium will analyze the data in the spring of 2001. Finally, the Consortium is using the findings of The Teaching Gap by James W. Stigler and James Hiebert (1999) to investigate how the teacher learning networks can improve instruction.

\section{The Regional Math/Science Collaborative}

Two major beliefs led to the creation of the Regional Math/ Science Collaborative in 1994: "a mathematically and scientifically literate population is essential to the social and economic success of southwestern Pennsylvania" and "by working together, we can do better." 7 The Collaborative, located in southwestern Pennsylvania, unites $100+$ school districts, approximately 15,000 mathematics and science educators, and hundreds of interested stakeholders, such as corporations, museums, foundations, and universities.
Determining what mathematics and science instruction currently looks like in the region, what it should look like, and how to bridge that gap formed the blueprint for the initiative. Once the answers to the first two questions were agreed upon by task forces, the Collaborative chose to 1) communicate the information through conferences, publications called the Journal and Coordi-net, and a continually updated web site ${ }^{8}$ 2) facilitate planning by conducting review sessions and preparing testimony on state standards; and 3) measure progress by gathering and evaluating achievement data.

Additionally, members of the Collaborative developed a resource binder titled Making National Standards and TIMSS Work for Our Region. The binder helps teachers and administrators combine the results of TIMSS with the National Science Education Standards and the National Council of Teachers of Mathematics standards so they can develop district-level action plans for curriculum and professional development. Many of the goals for students in the Collaborative's vision statement respond to TIMSS research findings on instructional practice. For example, students in the Collaborative will:

- Demonstrate problem-solving and critical thinking skills, requiring both team and individual effort and responsibility;

- Apply knowledge as well as its reproduction; and

- Engage in disciplined inquiry including an in-depth understanding of a problem and the integration of newly acquired information with the student's prior knowledge. ${ }^{9}$

The teacher questionnaire component of the TIMSS produced many findings that the Collaborative took into consideration. For instance, in the questionnaire, teachers were asked if they view mathematics and science as a 1) discipline with canons and formal processes; 2) set of procedures; or 3) process or way of thinking. Most U.S. teachers identify mathematics and science as a set of procedures first and foremost. By contrast, Japanese teachers more often see mathematics as a set of relationships between concepts, facts, and procedures and think mathematics is inherently interesting.

At the Forum, James Hiebert, an education professor at the University of Delaware and Co-Director for the videotape study, shared some of the results from the video component of the TIMSS. While examining 231 hours of videotapes of eighth grade mathematics classrooms in Japan, the United 


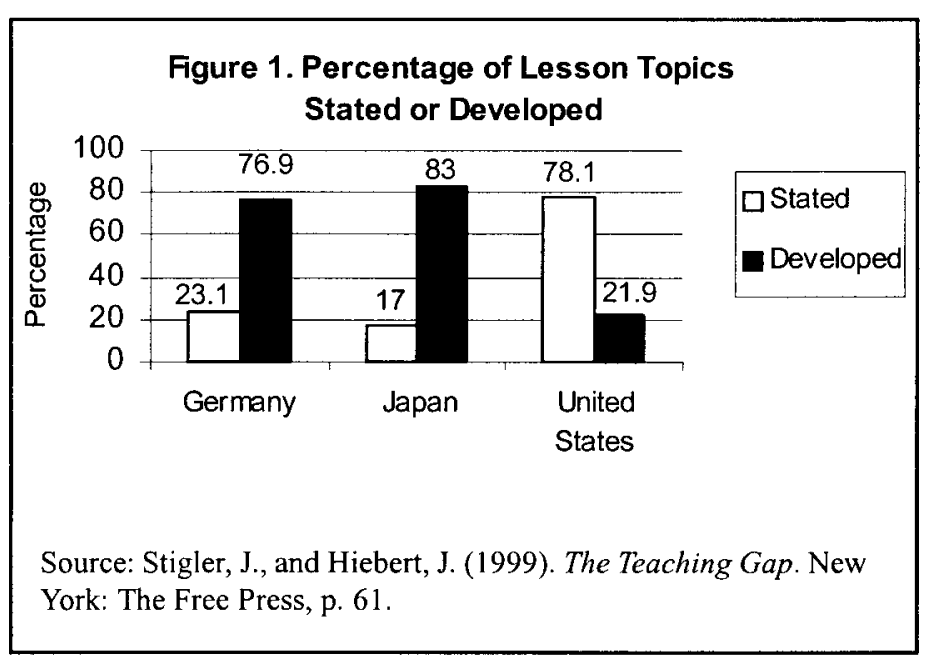

States, and Germany, researchers focused on teachers' goals for the lesson, whether mathematical concepts were "developed" or "stated" in the lessons, and the kind of reasoning required of the students during the lessons. Four university mathematics teachers assisted in judging the quality of the mathematics content of the lessons.

One important conclusion was that teaching methods are consistent with teachers' goals, which vary significantly across countries. For example, the goal of many U.S. teachers is to help students master mathematical procedures. In the typical mathematics lesson captured by the TIMSS, the U.S. teacher merely states the concept, demonstrates how to work the problems, and asks the students to practice the procedure on similar problems. Little time is spent developing connections and relationships between ideas; the focus is on practicing procedures (see Figures 1 and 2).

Teachers in the Regional Math/Science Collaborative have used these findings to reflect on their own practices, to set priorities, and to make connections. Some "Core Leadership Teams" within the Collaborative have formed study groups to view and discuss the video case studies. Others have established school visitations and peer coaching to observe techniques and instructional strategies.

\section{Paterson School \#2}

Lynn Liptak, the principal of Paterson School \#2 in Paterson, New Jersey drew on TIMSS findings to improve instruction and professional development at her elementary/middle school in which 98 percent of the students are eligible for free lunch. "We saw TIMSS as something we could use at the classroom level," said Liptak, "We saw it as a vehicle to tackle fundamental problems."
Figure 2. Percentage of Seatwork Time Spent in Three Kinds of Tasks

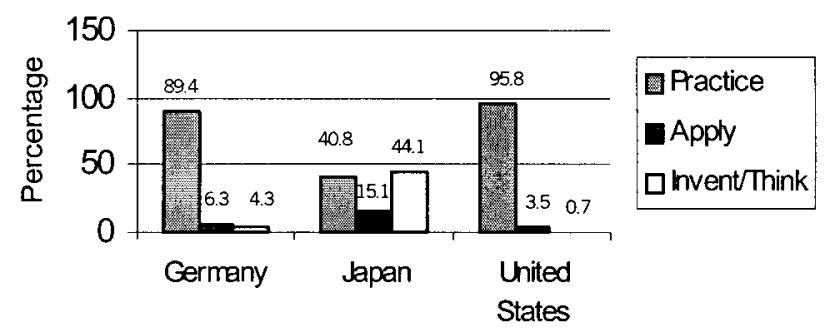

Source: Stigler, J., and Hiebert, J. (1999). The Teaching Gap. New York: The Free Press, p. 71.

Initially, Liptak and two teachers at the school, Bill Jackson and Beverly Piekema, viewed the TIMSS videotapes and studied the findings. With that information, Jackson and Piekema began writing their own curriculum, modeling it on the Japanese style with the help of colleagues over a twoyear period. They also redesigned their teaching methods. For example, Jackson now poses a thought-provoking problem that his students struggle with before they present possible solutions. The class discusses the solutions and Jackson uses their conclusions to instruct the class. He summarizes the lesson, relating it back to the original problem, and assigns students similar problems to practice.

To provide students with a concrete demonstration of what he wants when he asked them to present solutions, Jackson had his students watch and evaluate the TIMSS videotapes. "I thought it was very important for students to understand what I was attempting to do," said Jackson. "I [also] wanted to know what they thought of the TIMSS tapes (for example, Which lessons did they like better? Which looked like more fun? In which one did it look like they were learning?)."

When Jackson's students prepared to write lessons and teach younger students as part of a school project, he had them watch the TIMSS videotapes again. Jackson felt this experience sealed some of the ideas in their heads. "Some students [after leaving Paterson] have even given suggestions to their high school teachers on how to teach better!" said Jackson.

Hiebert cited additional benefits of the TIMSS videotape study at the Forum, saying it provides concrete examples to anchor discussions in teaching practice, a range of alternative practices with which to compare the U.S. system, and the support of rich data through multiple forms of analyses to test hypotheses. Hiebert warned, however, that teaching practices are part of an education system and, too often, unsuc- 


\section{Box 1 \\ Professional Development}

\section{Traditional}

- Begins with an answer.

- Driven by the expert trainer.

- Communication flow is from trainer to participants.

- Relationships are (tacitly) hierarchial.

- Research informs practice.

\section{Practical Inquiry}

- Begins with a question.

- Driven by the participants.

- Communication flow is conversation among participants.

- Relationships are reciprocal.

- Practice is research.

Source: PowerPoint presentation by Lynn Liptak. http://www.tc.columbia.edu/ceoi/eli Slide \#27.

cessful attempts to improve the U.S. education system stem from adopting another country's methods piecemeal. Importing whole systems doesn't work either, he explained, because systems of education are embedded in a country's culture. Liptak offered a similar conclusion based on her school's experiences saying, "This is not a panacea. The problems are systemic and fundamental, so the changes must be systemic and fundamental."

For professional development at Paterson School \#2, Liptak formed a voluntary, weekly mathematics study group that gave teachers time to explore ideas in math, to discuss current research, to plan lessons cooperatively, and to observe one another's teaching. Liptak explained, "If teachers are to teach in more powerful ways, they must have the opportunity to learn in more powerful ways."

The mathematics study group engaged in "practical inquiry" professional development. Unlike traditional professional development, practical inquiry begins with a question that teachers and principals explore together, tapping outside information, but also constructing knowledge from their own students and practice. (See Box 1 for the contrast between traditional and practical inquiry professional development as viewed by Liptak.)

The most recent form of practical inquiry that Paterson School \#2 is engaged in is the "lesson study," which aims to improve teaching and learning in whole systems. Paterson is working closely with the Greenwich Japanese School, a school run by the Japanese government for expatriates in the United States, to learn how to run a lesson study. Unlike the United States, Japanese teachers run their own professional development programs, which focus on these lesson studies. Catherine Lewis, a professor at Mills College who studied teachers in Japan, explained at the TIMSS Forum that lesson studies or "research lessons" are actual classroom lessons that are carefully planned, usually in collaboration with other teachers. Teachers identify a schoolwide theme, such as "developing initiative," and create, conduct, and evaluate lessons. The lesson is taught by one of the teachers and observed and discussed by other teachers to determine its strengths and weaknesses. Research lessons spread ideas for new content material and approaches, connect classroom practice to broader goals and policies, and help teachers learn about how students learn. ${ }^{10}$

\section{TIMSS Research Projects}

Several education researchers presented their ongoing work and future plans at the Policy Forum in Washington, D.C., including the projects listed below.

\section{University of Pennsylvania and Pennsylvania State University Project}

How can the science and mathematics achievement of American fourth, eighth, and twelfth grade students in international comparisons be explained? To answer this, professors from the University of Pennsylvania and Pennsylvania State University received conjoint grant funding from the U.S. Department of Education and the National Science Foundation to: a) analyze TIMSS data to identify factors that contribute to academic achievement in mathematics and science; and b) to disseminate the policy implications of their findings. ${ }^{11}$ The major components of the project include augmenting TIMSS by collecting additional national-level variables, performing secondary analyses of the augmented TIMSS data, and convening three annual TIMSS Policy Forums to disseminate and discuss TIMSS research findings. 


\section{Council of Chief State School Officers Project}

The Council of Chief State School Officers (CCSSO) under a grant from the National Science Foundation is conducting a study of state reform and systemic initiatives in mathematics and science. The study focuses on curriculum content and teaching practices in 11 states and compares those findings to state standards and initiatives. CCSSO uses TIMSS and NAEP data to pinpoint educational practices related to improved student performance. ${ }^{12}$

\section{Boston College Project}

Al Beaton, the Director of the Center for the Study of Testing, Evaluation, and Educational Policy located at Boston College, received a three-year grant from the National Science Foundation to work with a statistical model to examine the importance of students' socioeconomic status versus the effects of schools. The statistical model enables Beaton to look at mathematics achievement at the school and classroom levels and to separate student background from school variables.

\section{TIMSS Curriculum Data Project}

William Schmidt, Professor and Executive Director of the U.S. National Research Center on the TIMSS at Michigan State University, is conducting research on how much curriculum variables affect student achievement.

\section{Next Steps and the TIMSS-R}

This section of the Brief looks to the future and discusses how researchers and practitioners will be using the follow-up study to TIMSS - TIMSS-R or the Third International Mathematics and Science Study-Repeat - to further examine and possibly alter U.S. education policy and practice for the advancement of student learning. Focusing on eighth grade mathematics and science, the TIMSS-R replicates three components of the TIMSS: 1) the student assessment and background questionnaires for students and teachers; 2) the state and district benchmarking study; and 3) the videotape study. Currently, Australia, the Czech Republic, Hong Kong, Japan, Luxembourg, the Netherlands, Switzerland, and the United States are participating in the TIMSS-R video study.

TIMSS-R in its entirety enables researchers, practitioners, and policymakers to monitor trends in student achievement and to track four years later the progress of those students who took the TIMSS in the fourth grade. It collects more

\section{Box 2 \\ TIMSS-R State and District Benchmarking Participants}

- Connecticut

- Idaho

- Illinois

- Indiana

- Maryland

- Massachusetts

- Michigan

- Missouri

- North Carolina

- Oregon

- Pennsylvania

- South Carolina

- Texas

- Academy of School District \#20 (CO)

- Chicago Public Schools (IL)

- Connected Mathematics Project (MI)

- Delaware Science Coalition

- First in the World Consortium (IL)

- Fremont/Lincoln/West Side Public Schools (NE)

- Guilford County Schools (NC)

- Jersey City Public Schools (NJ)

- Miami-Dade County Public Schools (FL)

- Montgomery County Public Schools (MD)

- Naperville School District \#203 (IL)

- Regional Math and Science Collaborative (PA)

- Rochester City School District (NY)

- $\quad$ SMART Consortium $(\mathrm{OH})$

background information, such as professional development and teaching practice, as well as new data on countries, states, and districts that did not participate in TIMSS.

\section{Missouri}

Like many other states and districts (see Box 2), Missouri is participating in the TIMSS-R benchmarking study to see how the state compares on achievement scores to the United States and other countries. Missouri participated in TIMSS originally to verify the accuracy of the state test titled the Missouri Assessment Program (MAP). James Friedebach, the Director of Assessment, said that when Missouri state education administrators linked the TIMSS with the MAP, they found that student achievement in certain mathematics and science topics-specifically geometry, measurement, and physics—needed and subsequently received attention. 


\section{Box 3 Release Dates for TIMSS-R}

\section{TIMSS-R}

December 2000-January 2001-International and U.S. results.

\section{TIMSS-R State and District Benchmarking Study}

May 2001-Benchmarking reports.

September 2001—Benchmarking database.

\section{TIMSS-R Videotape Study}

August 2001-Report on mathematics teaching practices. August 2002-Report on science teaching practices.

\section{Contact Information}

National Center for Education Statistics (202) 219-1828

Boston College (617) 552-1600

The combination of the MAP and TIMSS helped launch two new initiatives: a mathematics initiative to build capacity across the state and a science initiative to improve student performance. Missouri also made use of the TIMSS data as part of "Interface Conferences" in which mathematics and science teachers from around the state met to discuss problems and solutions. TIMSS is now officially one of the Missouri Department of Education's strategic planning indicators.

Like Missouri, First in the World plans to participate in TIMSS$\mathrm{R}$ benchmarking study and will test the same seventh grade students who took the TIMSS in the fourth grade. First in the World also will participate in the TIMSS-R video study, as previously mentioned, but by taking a different approach. It will take two of the most difficult math and science lessons and compare them with the instructional practices of other leading countries. As part of the TIMSS-R video study, interviews will be conducted with teachers before and after lessons and with students after lessons. Multiple lessons over days will be conducted to follow the progression of the instruction, and these lessons will be compared with international counterparts.

The schedule for the release of the TIMSS-R data is contained in Box 3. For more information about TIMSS findings and research, TIMSS-R plans, and the practitioner initiatives mentioned in this Brief, see Box 4 for a listing of key web sites.

\section{Conclusion}

In the final remarks of the 1999 TIMSS Forum in Washington, D.C., Richard Elmore, Co-Director of CPRE and a professor at Harvard University, suggested that TIMSS is a benchmark, a tool for improvement, and a public good. The importance of TIMSS as a benchmark, Elmore asserted, will grow as other measures of accountability are allotted higher stakes. TIMSS can be used as a point of departure for education practitioners, administrators, and policymakers to ask themselves if their estimation of students' and schools' performance is correct and, as with Missouri, TIMSS-R surely will facilitate this process.

The district initiatives and Paterson School \#2 demonstrate the power of TIMSS as a tool for improvement, even without formally participating in the study. The videotape portion alone enables practitioners to see what researchers can otherwise only explain in the abstract.

Finally, commenting on TIMSS as a public good, Elmore said, "TIMSS has given the policy community a new way to think about recurring problems." Perhaps most important, TIMSS connects researchers and practitioners and gives the country both the impetus and the opportunity to engage in a largescale, public debate about education that is objective and informed.

\section{About the Author}

Marlies Dunson is CPRE's Dissemination Manager and is responsible for writing and editing policy briefs and conducting outreach efforts. Prior to joining CPRE, Dunson was a Researcher/Writer for the Office for Public Leadership at the Educational Testing Service and an Assistant Analyst and Production Editor for the Congressional Budget Office in Washington, D.C. She received an M.A. in elementary education from the University of South Florida and a B.A. in literature from Florida State University.

\section{Acknowledgments}

The author would like to thank Patsy Wang-Iverson of Research for Better Schools and Jill Edwards Staton of the U.S. Department of Education for their support and insightful comments on earlier drafts of this Brief. 


\section{Box 4 \\ Additional Resources}

\section{On TIMSS:}

U.S. TIMSS National Research Center at Michigan State University http://ustimss.msu.edu/middle.htm

The TIMSS Resource Center at the Mid-Atlantic Eisenhower Consortium (Research for Better Schools) http://www.rbs.org/

Regional Alliance at TERC http://ra.terc.edu/alliance/TEMPLATE/regional_networks/ cia/assessment/timss.cfm

American Federation of Teachers

http://www.aft.org//timss/newppt/index.htm

\section{On TIMSS Video Study:}

Article by James W. Stigler and James Hiebert http://www.pdkintl.org/kappan/kstg9709.htm

Feature Story by Steve Olson http://www.edweek.com/tm/vol-10/08candid.h10

\section{On TIMSS-R:}

TIMSS International Study Center at Boston College http://timss.bc.edu/

LessonLab Inc.

http://www.lessonlab.com/timss-r/index.htm

\section{On Practitioners' Efforts:}

First in the World Consortium

www.ncrel.org/fitw/homepage.htm

Missouri Department of Elementary and Secondary Education

http://services.dese.state.mo.us/

Paterson School \#2 Presentation http://www.tc.columbia.edu/ceoi/eli (click on Leadership)

SMART Consortium http://www.oai.org/SMART/

Regional Math/Science Collaborative http://www.csc.clpgh.org/collab/default.html

\section{End Notes}

\section{U.S. Department of Education TIMSS Kit.}

2. The questions come from First in the World's web site, the address for which is listed in Box 4 of this Policy Brief.

3. This document is aligned with Project 2061, the National Council of Teachers of Mathematics (NCTM), NAEP, Compendium of Standards, Japan, Singapore, and the California Mathematics Achievement Standards.

4. Schmidt, W., et al. (1999). "Facing the Consequences: Using TIMSS for a Closer Look at U.S. Mathematics and Science Education." Dodrecht, the Netherlands: Kluwer Academic Publishers, p. 26.

5. ibid.
6. Kimmelman, P. (1999). "Big Initiatives in Small Places." The School Administrator, January.

7. The source is the Regional Math/Science Collaborative's web site: http://www.csc.clpgh.org/collab/default.html

8. http://www.carnegiesciencecenter.org/collab

9. Ibid.

10. Lewis, C. (1998). "A lesson is like a swiftly flowing river: How research lessons improve Japanese education." American Educator, 22(4).

11. Erling Boe (Co-PI), Robert Boruch, and Susan Fuhrman of the University of Pennsylvania, and David Baker (Co-PI), Gerald Le Tendre, and Robert Kadel of Pennsylvania State University comprise the research team. 


\section{Suggested Readings}

Baker, D. (1997). Surviving TIMSS, or everything you blissfully forgot about international achievement studies. Phi Delta Kappan, 79(3), 246-247.

Darling-Hammond, L., and Ball, D. L. (1998). Teaching for high standards: What policymakers need to know and be able to do. Philadelphia, PA: Consortium for Policy Research in Education and National Commission on Teaching and America's Future.

Elmore, R. F. (1999). Building a new structure for school leadership. American Educator, 6-13, 42-44.

Forgione, P. D. (1998). Responses to frequently asked questions about $12^{\text {th }}$-grade TIMSS. Phi Delta Kappan, 79(10), 769-772.

Kriegel, R., and Brandt, D. (1997). Sacred cows make the best burgers: Developing change-ready people and organizations. New York, NY: Warner Books.

Lawton, M. (1998). Researchers trace nation's TIMSS showing to 'basics.' Education Week on the Web, February 18. http://www.edweek.org/ew/vol-17/23aaas.h17

Loucks-Horsley, S., Hewson, P. W., Love, N., and Stiles, K. E. (eds.) (1997). Designing professional development for teachers of science and mathematics. Thousand Oaks, CA: Corwin Press.

National Center for Education Statistics. (1999). Highlights from TIMSS. Washington, D.C.: Office of Educational Research and Improvement, U.S. Department of Education. NCES 1999-081.

National Research Council. (1999). Global perspectives for local action: Using TIMSS to improve U.S. mathematics and science education. Washington, D.C.: National Academy Press.

Rohlen, T. P., and LeTendre, G. K. (eds.). (1999). Teaching and learning in Japan. Cambridge, England: Cambridge University Press.

Schmidt, W. H. et al. (1999). Facing the consequences: Using TIMSS for a closer look at United States mathematics and science education. Dordrecht, The Netherlands: Kluwer Academic Publishers.

Slowinski, J., Laine, S., and van der Ploeg, A. (1999). Benchmarking against the TIMSS: Lessons from First in the World. Policy Issues, Issue 2, February. Oak Brook, IL: North Central Regional Educational Laboratory.

Stigler, J. W., and Hiebert, J. (1998). Teaching is a cultural activity. American Educator, 22(4).

Stigler, J. W., and Hiebert, J. (1999). The teaching gap: Best ideas from the world's teachers for improving education in the classroom. New York, NY: Free Press.

Stigler, J. W., and Hiebert, J. (1998). The TIMSS videotape study. American Educator, 22(4)

Tyack, D., and Cuban, L. (1995). Tinkering toward utopia. Cambridge, MA.: Harvard University Press.

Weiss, C. H. (1997). Evaluation: Methods for studying programs and policies. Upper Saddle River, NJ: Prentice Hall College Division.

Wilson, L. D., and Blank, R. K. (1998). Improving mathematics education using results from NAEP and TIMSS. Washington, D.C.: Council of Chief State School Officers, State Education Assessment Center. 


\section{Recent CPRE Publications}

District Leaders' Perceptions of Teacher Learning

James Spillane

February 2000 (No. OP-05) 31 pp., \$4

Examines district leaders' theories about teacher learning and change, identifying and elaborating three perspectives based on a study of nine school districts.

Improving State School Finance Systems: New Realities Create Need to Re-Engineer School Finance Structures Allan Odden

February 1999 (No. OP-04) 43 pp., \$6

Explores the inadequacies of state school finance systems and recommends short-term changes that states can make to their funding structures in order to accommodate more fundamental and long-term changes.

\section{Instruction, Capacity, and Improvement}

David Cohen and Deborah Loewenberg Ball

June 1999 (No. RR-043) 41 pp., \$10

Develops a theoretical view of instruction and then provides an analysis of the environments of instruction. Concludes with a discussion of the problems and possibilities for intervention.

School-Based Performance Award Programs, Teacher Motivation, and School Performance: Findings from a Study of Three Programs

Carolyn Kelley, Herbert Heneman III, and Anthony Milanowski

April 2000 (No. RR-044), \$10

Focuses on teachers' motivational reactions to school-based performance award programs, the degree to which teachers' motivational reactions are related to school performance, and principals' assessments of the effects of the programs.

To order, write: CPRE Publications, 3440 Market Street, Suite 560, Philadelphia PA 19104-3325. Prices include handling and book-rate postage (Add \$10 shipping and handling for delivery outside the U.S.). Sales tax is not applicable. For information on quantity discounts (over 25 copies), call 215/573-0700. Sorry, we cannot accept returns, credit card orders, or purchase orders. All orders must be prepaid with U.S. funds from U.S. banks; make checks payable to CPRE/Trustees of the University of Pennsylvania. Please allow 4-6 weeks for delivery.

\section{Research Reports from the National Research and Development Centers}

Need more research? Visit a new web site that links more than 600 reports from the 12 national R\&D centers. The site can be accessed at http://research.cse.ucla.edu/. Funded by the Office of Educational Research and Improvement, many centers conduct research that crosses specific education topics.

The new site is a joint product of the Organization of Research Centers communicators. 


\section{About CPRE}

The Consortium for Policy Research in Education (CPRE) unites five of the nation's leading research institutions to improve elementary and secondary education through research on policy, finance, school reform, and school governance. Members of CPRE are the University of Pennsylvania, Harvard University, Stanford University, the University of Michigan, and the University of Wisconsin-Madison.

CPRE conducts research on issues such as:

- education reform

- student and teacher standards

- state and local policymaking

- education governance

- school finance

- teacher compensation

- student incentives

\section{Nondiscrimination Statement}

The University of Pennsylvania values diversity and seeks talented students, faculty, and staff from diverse backgrounds. The University of Pennsylvania does not discriminate on the basis of race, sex, sexual orientation, religion, color, national or ethnic origin, age, disability, or status as a Vietnam Era Veteran or disabled veteran in the administration of educational policies, programs, or activities; admissions policies, scholarships, or loan awards; and athletic or University administered programs or employment. Questions or complaints regarding this policy should be directed to Executive Director, Office of Affirmative Action, 1133 Blockley Hall, Philadelphia, PA 19104-6021 or (215) 898-6993 (Voice) or (215) 898-7803 (TDD).

To learn more about CPRE or CPRE publications, please call 215/573-0700.

World Wide Web:

www.upenn.edu/gse/cpre/

www.wcer.wisc.edu/cpre/

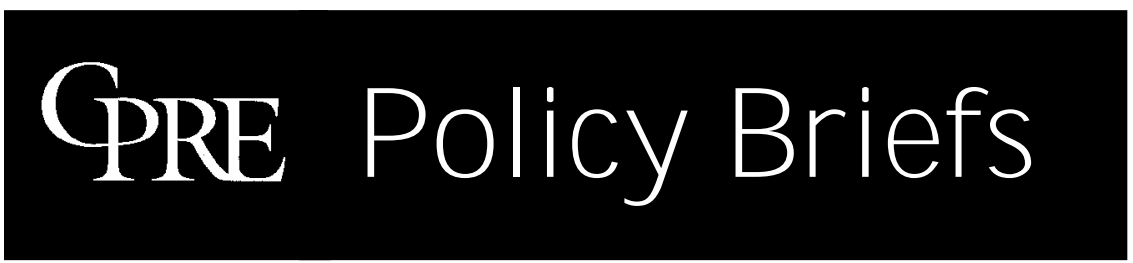

NON PROFIT

U.S. POSTAGE PAID

PERMIT NO. 2563

PHILADELPHIA, PA

Graduate School of Education

University of Pennsylvania

3440 Market Street, Suite 560

Philadelphia, PA 19104-3325 